\title{
JUVENTUDE E ESCOLA: PROBLEMATIZANDO REGRAS, SOCIABILIDADES E RELAÇÕES DE PODER
}

\author{
YOUTH AND SCHOOL: PROBLEMATIZING RULES, \\ SOCIABILITIES AND RELATIONS OF POWER
}

\author{
Fabrício Roberto Costa Oliveira ${ }^{26}$ \\ Cáio César Nogueira Martins ${ }^{27}$ \\ Deomario Lauriano Machado ${ }^{28}$
}

\section{Resumo}

Este artigo tem como objetivo problematizar as relações dos jovens com a escola em que estudam, focando na relação destes com as regras da instituição. Realizamos um grupo focal com estudantes de cinco turmas de terceiro ano do Ensino Médio. Durante a realização do grupo focal identificamos o alto grau de maturidade dos participantes, bem como a satisfação dos mesmos em serem ouvidos, entretanto restou evidente o descontentamento quanto às regras escolares, bem como seus lugares de fala dentro do ambiente escolar. Resultados indicaram muita dificuldade de um debate amplo e profícuo entre os estudantes e os responsáveis pela escola, sinalizando a necessidade de práticas mais dialógicas e projetos coletivos que promovam uma interação entre grupos dirigentes da escola e jovens.

Palavras-chave: Escola. Juventude. Regras escolares. Sociabilidade.

\begin{abstract}
This article aims to problematize the relationships of young people with the school in which they study, focusing on the relationship of these agents with the institution's rules. We conducted the focus group with students from five third year high school classes. During the realization of the focus group, we identified the high degree of maturity of the participants, as well as their satisfaction in being heard, however, discontent about school rules, as well as their places of speech within the school environment, remained evident. Results indicated the difficulty of a broad and fruitful debate among students and those responsible for the school, signaling the need for more dialogical practices and collective projects that promote interaction between school leaders and young people.
\end{abstract}

Keywords: School. School rules. Sociability. Youth.

\footnotetext{
26 Doutor em Ciências Sociais pela Universidade Federal Rural do Rio de Janeiro (UFRRJ). Professor da Universidade do Estado de Minas Gerais (UEMG). E-mail: fabrício.costa@uemg.br Orcid: https://orcid.org/0000-0002-5522-6192.

27 Licenciando do Curso de Ciências Sociais da UEMG/Barbacena. E-mail: caio martins.007@hotmail.com Orcid: https://orcid.org/0000-0003-4975-6688.

28 Licenciando do Curso de Ciências Sociais da UEMG/Barbacena. E-mail: deouemg@gmail.com Orcid: https://orcid.org/0000-0002-4765-0255.
} 


\section{RevistAleph}

\section{Introdução}

No Brasil contemporâneo as relações entre as juventudes e suas escolas são complexas e imersas num emaranhado de disputas. Entrar no mundo das escolas é participar de um universo rico de simbolismos e práticas, pois as escolas têm a capacidade de produzir uma cultura singular e original. Nossa atenção estará voltada mais especificamente para as relações entre juventude e uma escola pública do interior de Minas Gerais. Analisaremos as perspectivas dos jovens estudantes.

Em nossa sociedade, o termo juventude é quase naturalizado para se referir a anos de idades específicos. Não obstante, Ariès (1981) demonstra que em outros contextos históricos a precisão cronológica não se fazia tão necessária como na atualidade. Ele destaca que até o século XVIII as idades da vida não correspondiam apenas a etapas biológicas, mas a funções socialmente desempenhadas. Ele afirma que a adolescência fora confundida com a infância, e que só se saía da infância quando se tornava independente, capaz de prover o seu próprio sustento, o que reforça a ideia de que as idades estão muito relacionadas aos papéis sociais estabelecidos.

Ariès (1981) aponta que no século XIX a juventude tornou-se um tema literário e preocupação de moralistas e políticos, pois se começou a desejar saber seriamente o que ela pensava. "A juventude apareceu como depositária de valores novos, capazes de reavivar uma sociedade velha esclerosada" (ARIÈS, 1981, p.46). Estas representações são originárias de pressões demográficas e de transformações sociais que revelam mudanças em relação às formas com que se concebe a vida.

Faz-se necessário lembrar que as divisões etárias são arbitrárias, não servindo de parâmetro universal para delimitar o início e o término de cada uma das fases da vida. Para Bourdieu (2003), essas divisões são frutos de uma construção social e que as relações entre idade social e idade biológica são complexas, almejando impor limites e produzir uma ordem à qual cada um se deve ater, na qual cada um deve manter-se no seu lugar.

Ainda, segundo Bourdieu (2003), a perspectiva sobre a juventude pode variar de acordo com a condição econômica: enquanto os jovens burgueses buscam prolongar sua juventude, focando nos estudos, os jovens das classes mais populares buscam inserir-se rapidamente na vida adulta através do mundo do trabalho. A necessidade de independência econômica é apontada como uma das causas do abandono da formação escolar pelos 


\section{RevistAleph}

jovens das classes mais populares. Entretanto, muitos grupos que vivem experiências e expectativas muito diferentes entre si recebem a mesma denominação de juventude: “Entre duas posições extremas, o estudante burguês e, no outro extremo, o jovem operário que não chega sequer a ter adolescência, encontramos hoje toda a espécie de figuras intermediárias" (BOURDIEU, 2003, p. 154).

A concepção contemporânea é de que adolescentes e jovens devem estar no sistema educacional. Durkheim, clássico fundador da sociologia da educação afirma "a educação é a ação exercida pelas gerações adultas, sobre as gerações que não se encontrem ainda preparadas para a vida social" tendo como objetivo suscitar e desenvolver nos indivíduos mais novos certos estados físicos, intelectuais e morais esperados socialmente (Durkheim, 1965, p. 38). Neste caso, Durkheim (1965) corrobora uma visão de que há gerações não preparadas para a vida social e cabe à geração de adultos inculcarem-lhes ideias que os tornem aptos a viver em sociedade.

Esta reflexão indica três autores, Ariès (1981), Bourdieu (2003) e Durkheim (1965), que mostram perspectivas diferentes e interessantes para ajudar a pensarmos os jovens da escola em que realizamos a pesquisa. Ariès (1981) mostra como há uma relação direta entre as etapas biológicas e a função social a ser desempenhada e como a partir do século XIX a juventude se tornou importante objeto de reflexão. Bourdieu (2003) demonstra a necessidade de se ficar atento para as desigualdades entre as juventudes, já que os papéis sociais esperados estão diretamente relacionados às condições vida econômicas da família. Já Durkheim (1965), via na educação uma forma de produção de harmonia por meio de coerção. Tais perspectivas contribuem para que fiquemos atentos às expectativas da sociedade em relação aos jovens, às suas desigualdades e a imposições coercitivas da escola.

A concepção contemporânea é de que adolescentes e jovens devem estar no sistema educacional. Sabido é que a Constituição Cidadã garante aos cidadãos o acesso à educação formal de qualidade dos quatro aos dezessete anos, sendo um dever do Estado e da família, cujo objetivo almeja o pleno desenvolvimento da pessoa, seu preparo para o exercício da cidadania e a sua qualificação para o trabalho ${ }^{29}$. Como bem pontua Stecanela

\footnotetext{
${ }^{29}$ A Educação Básica brasileira está dividida da seguinte forma:

- Pré-escola: abarca os alunos entre 04 e 05 anos de idade;

- Ensino Fundamental: se subdivide em anos iniciais (compreende os cinco primeiros anos escolares, cujos alunos normalmente estão inseridos na faixa etária de 06 a 10 anos) e anos finais (compreendem os 


\section{RevistAleph}

(2018), o sistema de direitos que circunda as trajetórias de crianças e adolescentes brasileiros perpassa pela obrigatoriedade da frequência à escola, totalizando 14 anos de escolarização obrigatória durante a infância, adolescência e juventude.

O processo educacional no Brasil se operacionaliza através da separação dos indivíduos em turmas de acordo com a faixa etária, e a partir do aprendizado de conteúdos programados para serem ensinados a cada idade, estes alunos são promovidos para as etapas subsequentes, até percorrerem todas as séries da educação básica. Em linhas gerais, as escolas têm como um núcleo estruturante as salas de aula, com alunos organizados em fileiras e sentados de frente a um professor e uma lousa. Desta forma, "a escola parece perdida, inadaptada às circunstâncias do tempo presente, como se ainda não tivesse conseguido entrar no século XXI" (NÓVOA, 2019, p. 03).

Dayrell (2007) aponta que no Brasil, até o início década de 1990, dificilmente as pessoas com menor poder aquisitivo tinham a oportunidade de cursar o Ensino Médio. A partir do momento que as políticas governamentais atentaram-se a necessidade de fortalecer os investimentos na educação básica, as escolas começaram a receber um público cada vez mais heterogêneo, marcados pelo contexto de uma sociedade desigual, com altos índices de pobreza e violência. Ao mesmo tempo, ocorreu uma migração significativa dos alunos das camadas altas e médias para a rede particular de ensino.

Gil e Sefener (2016) mostram que diferentemente do Ensino Fundamental, o Ensino Médio não foi definido na Constituição de 1988 como de matrícula obrigatória. Entretanto, através da Emenda Constitucional no 59, de 11 de novembro de 2009, indicou o ano de 2016 para a conclusão deste processo de obrigatoriedade. O Ensino Médio tornava-se uma etapa da escolaridade obrigatória, tanto para ricos (que já cursavam na expectativa de ingressarem em um curso superior) quanto para os menos abastados (que vislumbravam a possibilidade de uma melhor colocação no mercado de trabalho).

Consoante os apontamentos de Bourdieu (2003), o papel da escola não se exaure no simples múnus de se ensinar saberes e técnicas, mas a conferir títulos e direitos para exercício de determinadas atividades no seio da sociedade. Para Chervel (1990) os efeitos sociais no processo de escolarização, frente à formação disciplinar, revelam a constituição

quatro anos escolares subsequentes, cujos alunos normalmente estão inseridos na faixa etária de 11 a 14 anos);

- Ensino Médio: são os três últimos anos da educação básica, cujos alunos normalmente encontram-se na faixa etária dos 15 aos 17 anos. 


\section{RevistAleph}

de uma cultura própria em cada ambiente escolar. Desta forma, dificultar o acesso ou limitar as oportunidades de estudo às classes populares nada mais serve do que um instrumento para se reproduzir e perpetuar as desigualdades.

Diante do exposto começamos a nos questionar como se dão as relações de sociabilidade entre os agentes adultos e o mais jovens nas escolas? Seria mais um espaço de disputas ou de aplicação de conceitos das gerações mais velhas sobre seus agentes mais jovens? Com se dão as relações de sociabilidades nas escolas? Como os jovens lidam com as regras da instituição escolar? Para levar adiante estas problematizações realizamos um grupo focal com estudantes de uma escola pública específica.

Nosso objetivo neste artigo é problematizar as relações entre jovens e a escola em que cursam o Ensino Médio. Procuramos entender mais especificamente como estes estudantes se socializam e lidam com as regras das escolas no cotidiano escolar. A motivação adveio da observação de estudantes do Ensino Médio por meio do PIBID $^{30}$ de Sociologia nos anos de 2018 e 2019. Estes alunos, ao interagirem com pibidianos no decorrer das aulas e no horário do recreio, se queixavam de que a escola poderia ter outras regras e ser mais permissiva em suas relações de sociabilidade. O contexto das objeções evidenciou que as normativas da escola eram pensadas e executadas pelos gestores escola e que os jovens estudantes não estariam inseridos nesta categoria de responsáveis pela existência do ambiente escolar.

\section{Metodologia}

Conforme narrado anteriormente, no transcorrer dos anos de 2018 e 2019 um grupo de bolsistas do PIBID teve a oportunidade de acompanhar as atividades da disciplina de Sociologia ministradas em uma escola pública situada em um município do interior do estado de Minas Gerais ${ }^{31}$. Naquela oportunidade, recebíamos relatos frequentes de que havia estudantes desestimulados e que questionavam regras de funcionamento da escola.

\footnotetext{
30 PIBID é o Programa Institucional de Iniciação à Docência que promove aproximação de licenciandos com a realidade cotidiana das escolas públicas da educação básica. No caso dos cursos de Ciências Sociais, os estudantes universitários acompanham as aulas da disciplina de Sociologia no ensino médio, estes são conhecidos como pibidianos.

${ }^{31}$ A cidade que abriga a escola está localizada na região do Campo das Vertentes de Minas Gerais e possui aproximadamente 130.000 (cento e trinta mil) habitantes, sendo considerada relevante do ponto de vista educacional por possuir instituições de ensino superior, públicas e privadas.
} 


\section{RevistAleph}

Nossa opção pelo grupo focal se deu pela percepção de que em grupo os estudantes se expressariam com maior facilidade. Para Yin (2016), o grupo focal é aconselhável metodologicamente em situações em que se acredita que as pessoas podem se expressar com mais facilidade do que quando são alvos de uma entrevista individual. Nosso pressuposto é que a expressão coletiva de dilemas envolvidos pelos alunos envolvidos na pesquisa potencializou as falas dos mesmos e trouxe informações importantes acerca de suas vivências escolares.

A escola em questão é uma instituição pública que oferece à população o serviço de educação básica e que está localizada próxima à região central da cidade. 0 educandário recebe alunos residentes em diversos bairros, funcionando em três diferentes turnos: manhã, tarde e noite. No turno da manhã funcionam as turmas de Ensino Médio, do 10 ao 3ㅇ ano. O turno da tarde abarca as turmas de Ensino Fundamental, do 1으 ao 9을 ano. No turno da noite funcionam as turmas de Educação de Jovens e Adultos (EJA).

Objetivando problematizar as relações dos jovens com a escola em que estudam, enfatizando as regras e a interação destes agentes com os gestores da instituição, realizamos um grupo focal ${ }^{32}$ composto por membros das cinco turmas de Terceiro Ano do Ensino Médio - série final da educação básica. Era estudantes que potencialmente teriam cursado todo ou parte do Ensino Médio naquele estabelecimento de ensino, motivo pelo qual teriam mais propriedade para falarem sobre a escola. A presença de integrantes de todas as turmas era interessante para que tivéssemos uma amostra que melhor ilustrasse o que pensavam aqueles jovens sobre a escola em que estudavam.

O grupo focal se reuniu no dia 13 de novembro de 2019, nas dependências da escola, durante o horário das aulas, e contou com a participação de 16 (dezesseis) alunos selecionados a partir dos critérios de gênero, classe social e pertencimento étnico-racial, buscando um equilíbrio de representatividade. A escolha contou com a mediação do professor regente da disciplina de Sociologia, por melhor conhecer o perfil dos alunos.

Iniciado os trabalhos, deixamos que os participantes se sentissem à vontade para escolherem o local onde sentarem. Explicamos que se tratava de uma atividade que envolvia os bolsistas do PIBID e que iniciaríamos uma conversa acerca da juventude e suas relações com a escola. Informamos que a identidade dos participantes seria mantida no anonimato para não constranger/inibir as falas dos mesmos. Atribuímos um número a cada

\footnotetext{
${ }^{32}$ No tópico metodologia constam detalhes relacionados ao grupo focal. 


\section{RevistAleph}

um dos participantes a fim de facilitar a identificação posterior das falas, momento em que também distribuímos um questionário para melhor compreender o perfil dos participantes.

No quadro abaixo apresentamos uma caracterização dos estudantes obtida através da tabulação dos questionários:

Quadro 1: Perfil de estudantes participantes do Grupo Focal

\begin{tabular}{|c|c|}
\hline Gênero & $\begin{array}{l}08 \text { participantes se declararam do sexo Masculino }(50,0 \%) \text {, e outros } 08 \text { se } \\
\text { declararam do sexo Feminino }(50,0 \%)\end{array}$ \\
\hline Sexualidade & $\begin{array}{l}1 \text { participantes se declararam Heterossexuais }(68,75 \%), 4 \text { se declararam } \\
\text { issexuais }(25,0 \%) \text {, e apenas um se declarou Homossexual }(6,25 \%) \text {; }\end{array}$ \\
\hline Idade & $\begin{array}{l}06 \text { alunos afirmaram possuir } 17 \text { anos (37,5\%), outros } 08 \text { afirmaram possuir } 18 \\
\text { anos }(43,75 \%), 02 \text { afirmaram ter } 19 \text { anos }(12,5 \%) \text { e apenas um afirmou ter } 20 \\
\text { anos }(6,25 \%) \text {; }\end{array}$ \\
\hline Cor/Raça & $\begin{array}{l}07 \text { alunos se declararam Brancos }(43,75 \%) \text {, outros } 07 \text { se declararam Pardos } \\
(43,75 \%) \text { e } 02 \text { se declararam Negros/Pretos }(12,5 \%) ;\end{array}$ \\
\hline $\begin{array}{l}\text { Bair } \\
\text { resic }\end{array}$ & $\begin{array}{l}\text { participantes informaram residirem nas proximidades da escola }(37,5 \%) \text {, e } \\
\text { ttros } 11 \text { informaram residirem em bairros mais afastados da escola }(62,5 \%) \text {; }\end{array}$ \\
\hline $\begin{array}{l}\text { Deslocamento } \\
\text { a escola: }\end{array}$ & $\begin{array}{l}07 \text { alunos informaram ir a pé }(43,75 \%), 05 \text { de Van }(31,25 \%), 02 \text { de Ônibus } \\
(12,5 \%) \text { e outros } 02 \text { de Carro }(12,5 \%) ;\end{array}$ \\
\hline Renda familiar & $\begin{array}{l}10 \text { participantes não informaram/não souberam }(68,75 \%) \text {, } 01 \text { participante } \\
\text { informou ser próxima a } 1 \text { s.m. }(6,25 \%), 2 \text { informaram ser próxima a } 2 \text { s.m. } \\
(12,5 \%), 1 \text { informou ser próxima a } 3 \text { s.m. }(6,25 \%), 2 \text { informaram ser próxima a } 3 \\
\text { s.m. (12,5\%) e } 1 \text { informou ser próxima a } 4 \text { s.m }(12,5 \%) \text {; }\end{array}$ \\
\hline Escolaridad & $\begin{array}{l}03 \text { alunos informaram que seu genitor possui como escolaridade Ensino } \\
\text { Fundamental Incompleto }(18,75 \%), 05 \text { informaram que o genitor possui Ensino } \\
\text { Médio Completo }(31,25 \%), 01 \text { informou que seu genitor possui Curso Superior } \\
(6,25 \%), 01 \text { informou que seu genitor é Analfabeto }(6,25 \%) \text { e } 06 \text { optaram por } \\
\text { não informar/não sabem; }\end{array}$ \\
\hline $\begin{array}{l}\text { Escolaridad } \\
\text { mãe }\end{array}$ & $\begin{array}{l}03 \text { alunos informaram que sua genitora possui como escolaridade Ensino } \\
\text { Fundamental Incompleto }(18,75 \%) \text {, } 04 \text { informaram que a genitora possui como } \\
\text { escolaridade Ensino Fundamental Completo }(25,0 \%) \text {, } 02 \text { informaram que a } \\
\text { genitora possui Ensino Médio Incompleto }(12,5 \%) \text {, } 05 \text { informaram que a } \\
\text { genitora possui Ensino Médio Completo }(31,25 \%) \text { e } 02 \text { optaram por não } \\
\text { informar/não sabem; }\end{array}$ \\
\hline $\begin{array}{r}\text { Tem } \\
\text { estudan }\end{array}$ & $\begin{array}{l}02 \text { alunos disseram estudar na escola há } 1 \text { ano }(12,5 \%), 01 \text { disse estudar há } 2 \\
\text { anos }(6,25 \%), 07 \text { disseram estudar há } 3 \text { anos }(43,75 \%), 02 \text { disseram estudar há } \\
4 \text { anos }(12,5 \%), 02 \text { disseram estudar há } 7 \text { anos }(12,5 \%), 01 \text { disse estudar há } 8 \\
\text { anos }(6,25 \%) \text { e } 01 \text { disse estudar há } 11 \text { anos }(6,25 \%) ;\end{array}$ \\
\hline $\begin{array}{l}\text { Exercer atividade } \\
\text { laboral }\end{array}$ & 10 alunos informaram não exercer (62,5\%) e 06 informaram exercer $(37,5 \%) ;$ \\
\hline $\begin{array}{l}\text { Pretensão } \\
\text { Universitária }\end{array}$ & m que $\operatorname{Sim}(93,75 \%)$ e apenas um participante optou \\
\hline Quem fez Enem? & $\begin{array}{l}\text { afirmaram que Não }(50,0 \%) \text { e outros } 8 \text { participantes afirmaram } \\
\text { ); }\end{array}$ \\
\hline
\end{tabular}

Fonte: Acervo da pesquisa. 


\section{RevistAleph}

Havia oito meninos e oito meninas que tinham entre si uma diversidade sexual. Eram pessoas oriundas de família de baixo poder aquisitivo e baixo grau de escolarização, apenas o pai de um dos dezesseis participantes possuía ensino superior. Chama atenção o fato de que a maioria tem desejo de fazer curso superior, mas apenas $50 \%$ dos participantes fizeram o Enem, a principal forma de ingresso no ensino superior. Trata-se, então, de jovens de classes populares que sonham em continuar estudando mais suas realidades cotidianas mostram uma dificuldade de realizar tal sonho de forma mais imediata.

\section{A Escola como espaço de regras e sociabilidade}

O Ensino Médio brasileiro tem sido constantemente debatido por políticos, pesquisadores, professores e Ministério da Educação com a finalidade de encontrar soluções para que as altas taxas de repetência e evasão, bem como para que estudantes deixem este grau de ensino com melhor formação para ingressar no ensino superior e ou mercado de trabalho.

Segundo Dayrell (2007) atualmente os conflitos emergem quando professores, alunos e famílias se culpam mutuamente pelo fracasso escolar. É comum escutar que os estudantes da educação básica têm chegado aos anos finais despreparados, mal sabem ler e escrever. Ao ouvir os pais de estudantes do Ensino Médio, comumente escutamos a necessidade de procurar uma escola boa para seus filhos, porque, em geral, elas são muito fracas. Em rodas de professores são frequentes os comentários sobre as dificuldades em se trabalhar com os estudantes. Isso tem gerado o que Stecanela (2018) considera uma cultura da reclamação nas escolas em que os agentes pouco dialogam sobre soluções, o que é corroborada pelos queixumes de ambos sobre o papel que o outro desempenha, demonstrando uma relação pedagógica conflituosa.

Neste sentido, Dayrell (2007) afirma que para a escola e seus profissionais o fracasso na relação entre jovens e escola está relacionado com o pretenso individualismo e consequente desinteresse juvenil pela educação escolar. Sob a ótica dos jovens, a escola se mostra distante de seus interesses, tornando-se cada vez mais uma obrigação necessária, tendo em vista a necessidade de um diploma para melhor inserção no mercado de trabalho.

Em meio a essa trama de acusações e disputas pela explicação do fracasso, milhões de estudantes frequentam suas escolas diariamente. Em geral, gostam do ambiente escolar 


\section{RevistAleph}

e fazem dela o principal espaço de sociabilidade para além de suas casas e famílias, fato que restou evidenciado através dos relatos colhidos ao longo do grupo focal.

Homem 03: Gostar mesmo, eu gosto de ficar em casa, realmente, venho comer e jogar truco.

Mediador: Mas comer e jogar truco, são coisas que a escola te proporciona!

Homem 05: Nada, a escola é o baralho.

Mediador: Mas no intervalo pode jogar, não é?

Homem 04: Pode, mas se o "tiozinho" chegar e falar:acabou, me dá isso ai - aí já era!

Mediador: Da galera aqui, quem aqui gosta da escola?(Todos levantam as mãos).

Mulher 02: É um ambiente diferente, de conviver com as diferenças.

Homem 02: Não tem como não gostar, é aconchegante, você vem, encontra os colegas.

Homem 04: Eu não gosto da escola, eu gosto de vir pra escola e o que ela me proporciona.

Os participantes demonstram muita satisfação com alguns momentos como comer e jogar truco, mas este último só pode ocorrer às escondidas, e pelo que percebem os pibidianos sempre ocorrem. Trata-se de uma regra definida por quem possui o maior poder da decisão, os dirigentes da escola. Estudantes possuem um discurso resignado de que tudo acaba caso sejam vistos pelo "tiozinho" que trabalha na escola. Eles estavam em acordo de proibir no horário de aulas em razão do barulho, mas não no horário de folga, o recreio.

Interessante o fato de uma estudante colocar a importância de conviver com as diferenças, o que reforça a importância do papel socializador da escola. Contudo, essa sociabilidade não é sempre bem entendida na escola, há uma falta de diálogo em relação à cultura juvenil.

Mulher 04: Eu entrei na escola esse ano e não entendi a separação de turmas de meninos e de meninas, até hoje não entendo isso.

Mediador: Separação de quê?

Mulher 02: A fila da merenda. É uma fila que tem ficha pra menino e ficha para menina.

Mulher 01: E, assim que começou esse negócio de ficha, a gente já brigou, quebrou o pau. Sempre foi dividido, menina pra cá e menino pra lá. Mas, às vezes, a gente ficava misturado, bolinho de amigo... e, às vezes, ficava em uma fila só e não tinha problema...

Mulher 03: No começo do ano deu até briga porque eu e uma amiga minha estávamos na fila dos meninos...e levaram a gente pra secretaria porque estávamos na fila dos meninos e, aí, começou aquele negócio da ficha azul e da ficha rosa. Azul pra menino e rosa pra menina... 


\section{RevistAleph}

Mulher 02: Bem Damares ${ }^{33}$, ridículo!

Mulher 01: É uma coisa sem noção, ficar dividindo os gêneros, que a escola deveria não fazer!

Homem 02: Separam as amizades, separam os casaizinhos de namorado... Mulher 02: Pra no final todo mundo sentar na mesma mesa, comer a mesma coisa.

Por este diálogo percebe-se que a escola tende a tratá-los de forma homogênea, como já afirmara Bourdieu (2003), ignorando as particularidades e identidades dos estudantes e também de seus diversos grupos. Não se tem conhecimento de práticas semelhantes a esta nas demais escolas do município, o que nos leva a acreditar que não se trata de norma instituída pela Superintendência de Educação, e sim uma deliberação do corpo gestor do estabelecimento e que pode, eventualmente, constranger alguns alunos.

Tanto no truco, como nas conversas na fila da merenda algumas práticas juvenis, que num sentido mais amplo fazem parte de uma cultura, são proibidas na escola. Isso condiz muito com a perspectiva de Dayrell (2007) sobre o fato de que a escola tende a não reconhecer o jovem existente no aluno, muito menos compreender a diversidade (seja étnica, de gênero ou de orientação sexual) com a qual a condição juvenil se apresenta. Situação similar acontece em relação à vestimenta, quando alunos e alunas gostariam de ter liberdade de expressarem seus gostos e não podem.

Homem 01: O que eu menos gosto é essa coisa de ficar regulando uniforme.

Mulher 01: Eu acho meio desnecessário, tem dia que está muito frio e a moça da portaria fica pedindo pra gente levantar o casaco pra ver se a gente tá de uniforme mesmo ou não.

Mulher 02: Eu acho desnecessária a preocupação excessiva com coisa boba e tipo, largar o que realmente importa para lá.

Mediador: O que seria coisa boba e o que realmente importa?

Mulher 01: A preocupação com nossa vida mesmo né, pessoal... como vou dar um exemplo agora?!

Homem 02: Coisas como uniforme, coisas fúteis... tá ligado, tipo um aluno não pode entrar sem a camisa do uniforme mas pode entrar com drogas... tipo isso.

Mulher 01: Não, é um pouco pesado isso ai...

Homem 02: Droga até que parou né...

33 Damares Regina Alves é uma pastora evangélica e atual Ministra da pasta da Família, Mulher e Direitos Humanos no governo do presidente Jair Bolsonaro. Conhecida por defender pautas conservadoras, apareceu no dia 02 de janeiro de 2019 em um vídeo divulgado na internet comemorando a vitória de Bolsonaro e afirmando que uma nova era se iniciava no Brasil, em que "menino veste azul e menina veste rosa", em oposição aos avanços sociais quanto à liberdade de gênero. https://www.youtube.com/watch?v=bru1ffScYg. Acessado em: 26/05/2020. 


\section{RevistAleph}

Os estudantes percebem questões na escola que os preocupa mais que o uniforme. A questão das drogas é emblemática. Não é permitido entrar com droga, evidentemente, mas é mais difícil de controlar isso do que o uniforme. Suas formas de vestir típicas acabavam sendo proibidas. Para os jovens, a escola se tornara um ambiente recheado de normas que pouco condizia com seus interesses culturais. Outra norma bastante questionada é o rigor do horário que não é estendido aos docentes:

Mulher 03: Esse negócio de atraso também é muito chato, que pelo menos a gente veio na escola, não pode atrasar cinco minutos que a gente tá levando uma ocorrência gente, que doideira.

Mulher 02: Aí, se tu vem atrasado reclama, se não vem reclama...

Homem 03: Acho que deveria ter uma tolerância.

Mulher 02: A tolerância até tem, mas tipo igual eu, moro lá em baixo e subo o morro e chego aqui suando, às vezes atrasada, aí falam nossa você chegou atrasada, cara, eu cheguei, eu pelo menos estou aqui!

Homem 03: Sobre a questão do horário mesmo, se tivesse um tempo de chegada, tipo sete horas aqui na escola, eles deveriam ter começado isso desde o começo do ano, eles sempre começam no finalzinho. Eu estudo aqui desde o primeiro ano e sempre cheguei aqui no mesmo horário, 7:10 - 7:15. Outro dia eles vieram falar que eu estava chegando atrasado, mas era o mesmo horário. Igual, eles falam que 7:00 o professor chega em sala de aula, só que se você chega 7:00 em sala de aula e não tem professor, ele chega entre 7:10 e 7:15 junto com os alunos. Às vezes, os professores chegam mais atrasados que os alunos.

A estudante é muito enfática sobre a necessidade de maior valorização de sua presença e o quanto anda para chegar à escola a pé. Trata-se de estudantes de baixa renda, e que se sentem desestimulados pela estrutura da escola e pelo próprio desestímulo dos professores. São estudantes que já não sentem muito prazer em frequentar as aulas, são muitas regras pouco condizentes com seus interesses juvenis. Pelos relatos seus atrasos não atrapalham o funcionamento das aulas, porque são ínfimos em relação aos atrasos dos docentes. Uma punição que teria sido consolidada durante o transcurso do ano escolar, e não no início, assim como a regra do cartão de ida ao banheiro:

Homem 04: Igual agora, no último bimestre, eles colocaram um negócio de um cartãozinho pra ir ao banheiro. Você vai com ele no bolso e volta com ele no bolso, que ninguém olha, ninguém faz nada.

Mulher 01: Tá vendo, isso que eu acho inútil. É uma preocupação muito inútil.

Mulher 02: É uma cobrança que está sendo feita com muito atraso.

Homem 03: Além da falta de higiene do cartãozinho, porque a gente vai ao banheiro, pega o cartãozinho e passa pra outra pessoa. Tipo, se colocar 


\section{RevistAleph}

esse tipo de regra, que se coloque no começo do ano, antes de começar as aulas...

Homem 04: $O$ que eles não cobram no ano inteiro chega nos dois últimos meses eles começam a cobrar.

Os estudantes além de não verem sentido em algumas regras questionam a forma como são colocadas, como no final do ano letivo. Assim, professores, alunos e funcionários vivem numa disputa sobre a imposição e cumprimentos das regras. Trata-se de uma trama complexa entre os sujeitos envolvidos, quais sejam:

Alunos, professores, funcionários, pais - que incluem alianças e conflitos imposição de normas e estratégias, individuais e coletivas de transgressão e de acordos; um processo de apropriação constante dos espaços, das normas, das práticas e dos saberes que dão forma à vida escolar (DAYRELL, 2007, p. 1118).

Interessante ressaltar que as reclamações das normas e as dificuldades de interação com processos escolares não impedem que os estudantes e funcionários da escola se unam para resolver problemas coletivos. Os participantes disseram aprovar o projeto de revitalização da qualidade dos banheiros desenvolvido pelos alunos e pela bibliotecária da escola:

Homem 02: Eu achei maneira essa iniciativa de colocar as coisas no banheiro, diminuiu um pouco o fedor no banheiro masculino, na moral...

Mulher 02: Eu também achei legal.

Mediador: Expliquem melhor isso.

Mulher 01: Tipo, a nossa turma teve a iniciativa do setembro amarelo que era colocar frases no banheiro, de incentivo sabe, então a gente resolveu fazer isso e também ajudar na limpeza dos banheiros, porque tem vez que se chega lá e não aguenta. Igual teve um dia que a gente foi arrumar o banheiro masculino e tinha cocô no chão.

Mediador: Agente quem?

Mulher 03: É que eu e o pessoal da biblioteca, todo dia de manhã, a gente entra lá enquanto não tem ninguém e coloca papel higiênico, pasta de dente, sabe.

Mulher 01: A gente mesmo traz, às vezes as meninas trazem absorventes para deixar lá no banheiro para o próximo usar. Eu achei legal também.

Na sociabilidade emergem soluções e projetos para a própria escola. Jovens que por vezes são pensados apenas como questionadores de regras e indisciplinados, são aqueles que trabalham fora e ajudam no orçamento da família, cuidam de irmãos mais jovens e andam longe para chegarem à escola. Muitas vezes, os alunos são questionadores de regras por estas não serem consideradas legítimas. Para Dayrell (2007), tal fato resvala 


\section{RevistAleph}

na questão da autoridade, onde os alunos não se mostram dispostos a reconhecer a autoridade do professor como natural e óbvia. Assim, "continuam lidando com os jovens com os mesmos parâmetros consagrados por uma cultura escolar construída em outro contexto" (DAYRELL, 2007, p. 1125). Isso fica evidenciado, por exemplo, pelo fato dos gestores e das escolas não debaterem com seus alunos sobre as regras da escola ou sobre maneiras de solucionar problemas existentes.

De forma alguma este texto propõe ausência de regras, mas sim a necessidade de diálogo. Assim como Gil e Seffner (2016), concordamos que a escola deve fazer um esforço para dialogar com as culturas juvenis, tratando o aluno de ensino médio como alguém que é portador de ideias, proposições acerca do mundo, visões políticas e gostos culturais próprios. A respeito do sentimento que nutrem pela escola, os participantes teceram críticas:

Mediador: Que sentimento vocês têm em relação à escola?

Mulher 02: Acho a escola cansativa...

Mulher 03: Eu me sinto muito presa, na minha outra escola eu tinha muito mais liberdade. Tem um ano que estou aqui. Às vezes, a gente tem horário vago, o professor faltou, não pode sair de sala, se tiver aqui embaixo você leva ferro, não pode ir embora cedo se o professor do último horário faltou...

Mulher 02: Teve um dia que a gente só teve uma aula, dentro dos cinco horários, e a gente teve que ficar aqui. E eles reclamam ainda, porque a gente tem que ficar dentro de sala, olhando pro teto, e a gente não pode nem falar porque vai atrapalhar outra turma.

Homem 02: Primeiro, se liberassem não ia ficar todo mundo num lugar só conversando, não ia aumentar o tom de voz, e não ia atrapalhar todo mundo. la espalhar as turminhas, espalhar as conversas e não ia atrapalhar ninguém.

Mediador: Vamos entender que às vezes todo mundo está com 17, 18 anos, outros tem mais e tal, e ficam tratando todo mundo igual criança, preso em uma sala e tal, esse é um argumento interessante. Outro argumento pode ser o do cara da escola: a partir do momento que você entra aqui, se eu te libero pra rua pode acontecer alguma coisa e eu sou processado.

Mulher 02: A gente não pode ser liberado mais justamente por causa de uma briga que teve...

Homem 03: A briga não foi aqui, a menina saiu daqui, foi na Escola " $A$ " e apanhou...

Mediador: Aqui é uma escola que tem briga?

Homem 02: Não, já teve muita antigamente, quando eu entrei há uns 07 anos. Tinha muita briga, com a direção arrumando diminuiu. 


\section{RevistAleph}

É uma escola com muitas regras que os estudantes não reconhecem a legitimidade.

Ariès (1981) já demonstrava que a juventude estava relacionada a papéis específicos em outros contextos históricos, aqui parece vinculada à função de cumprir regras. Nesta perspectiva há uma interessante reflexão:

Em um modelo ideal, muito próximo àquele que regia o mundo do trabalho e o trabalhador, esperava-se que o aluno fosse disciplinado, obediente, pontual e se envolvesse com os estudos com eficiência e eficácia. Ao mesmo tempo, não se considerava os alunos na sua dimensão de jovens, numa tendência em representar ambos os conceitos como se fossem, de alguma forma, equivalentes (DAYRELL, 2007, p. 1119).

A interiorização das regras escolares é tanto mais difícil quanto mais sem sentido para os jovens que sentem ausência de um canal em que pudessem conversar e/ou questionar regras que devem cumprir cotidianamente. Para os estudantes há uma barreira entre os servidores da escola e eles, o que leva a uma ausência de diálogo entre as partes. Embora os alunos tenham informado que encaminham suas demandas à direção da escola, não percebem resultados efetivos:

Mulher 04: Eu estranho muito a abordagem também, a abordagem das pessoas que organizam, a abordagem que eles têm com os alunos é meio estranha, meio ríspida, eles não querem ter contato com os alunos. Às vezes a gente quer falar sobre a escola mesmo, só que eles têm um receio, mas querem cobrar umas coisas que realmente não tem nada a ver.

Mediador: Vocês têm algum Grêmio, alguma forma de representação?

Homem 02: Não, temos só o líder de turma.

Mulher 01: la ter em 2017, em 2017 até rolou um negócio de fazer o Grêmio mesmo, mas não foi pra frente.

Mediador: As demandas que vocês estão colocando pra gente evidentemente são sigilosas, mas são demandas que já chegaram à diretoria ou a alguém da supervisão de alguma forma, ou não?

Homem 02: Não chegou!

Mulher 03: Mas, mesmo se chegar eles não vão dar ideia.

Mediador: Por que você acha?

Mulher 01: Acho que essas coisas chegam lá, a gente reclama muito.

Homem 03: Depois que a Cristina ${ }^{34}$ assumiu ali o contato com a direção ficou mais fácil, sei lá, aluno pra direção ficou mais amigável.

Mulher 02: Ficou mais fácil, mas ainda não resolve muita coisa, ela só escuta mesmo, tipo você fala, ela te dá atenção, mas resolver o problema mesmo ela não resolve não.

Mulher 01: Verdade.

Homem 03: Acho que pra criar esse elo tinha que ter um Grêmio Estudantil mesmo, esse elo entre aluno e diretoria...

34 Optamos por substituir o verdadeiro nome por outro fictício a fim de proteger a integridade da escola e de seus servidores. 


\section{RevistAleph}

Mulher 01: Mas, ainda, acho que a direção não vai escutar a gente, na minha cabeça ninguém escuta a gente. É menos problema pra eles deixar de escutar do que ficar escutando e resolvendo o problema de cada um. A gente já está saindo mesmo.

Há uma demanda de escuta permanente que é acompanha de grande ceticismo em relação à solução. Parece que a expectativa é que na escola o jovem se transfigure em aluno disciplinado e dedicado. As ricas experiências sociais, culturais, laborais e familiares deveriam ficar fora da vida na escolar, local de disciplina e aprendizado. Os jovens vão para a escola como algo naturalizado, enxergam a presença na escola como uma necessidade condicionante à aprovação. Em geral, os estudantes frequentam escolas, motivados pela expectativa de "ser alguém no futuro" e não por prazer no tempo presente. Neste sentido, há grandes desafios bem traduzidos nas palavras de Dayrell (2007):

Para a escola e seus profissionais, o problema situa-se na juventude, no seu pretenso individualismo de caráter hedonista e irresponsável, dentre outros adjetivos, que estaria gerando um desinteresse pela educação escolar. Para os jovens, a escola se mostra distante dos seus interesses, reduzida a um cotidiano enfadonho, com professores que pouco acrescentam à sua formação, tornando-se cada vez mais uma "obrigação" necessária, tendo em vista a necessidade dos diplomas (DAYRELL, 2007, p. 1106).

Como vimos na escola que analisamos, o cotidiano tende a ficar sobrecarregado de regras enfadonhas, não obstante, é, por vezes, o local mais frequentado por eles nesta fase da vida. Em geral, os momentos mais prazerosos e mais significativos acontecem fora da sala de aula. É onde possuem mais autonomia para expressar sentimentos e emoções.

Para a grande maioria dos jovens brasileiros o cotidiano é extremamente difícil, a luta pela sobrevivência torna-se uma prioridade. Essa realidade foi constatada através dos participantes do grupo focal: renda baixa, pouca escolaridade dos pais e 06 pessoas afirmaram já trabalharem para ajudar nas despesas da família.

Muitas vezes os professores ao falarem do Enem e das universidades estão tratando de algo sonhado pelos estudantes, mas por vezes muito distante da realidade:

Mediador: Dessa galera aqui quantas pessoas estão fazendo Enem? (8 pessoas levantaram a mão - 4 homens e 4 mulheres) Quem não fez? ( 8 pessoas levantaram a mão - 4 homens e 4 mulheres) Quem não fez pretende terminar o ensino médio e não continuar estudando, ou tem outra forma de ingressar na faculdade?

Mulher 02: Quero continuar estudando, só não quis fazer o Enem esse ano mesmo, ano que vem estamos lá. Eu nem sei o que quero fazer ainda. 


\section{RevistAleph}

Homem 03: A galera põe muita pressão pra fazer Enem... Enem! Enem! Enem!

Mediador: Foi uma opção não fazer ou vocês perderam data?

Mulher 03: Foi opção, eu não me senti preparada e resolvi não ir. Vou me preparar, estudar melhor e fazer ano que vem.

Mulher 02: Não fiz por não saber qual curso fazer.

Mediador: $\mathrm{E}$ a escola estimula vocês a fazerem o Enem?

Homem 02: Estimulam, mas o estímulo deles é meio diferente...

Mulher 02:Às vezes é mais os professores mesmo.

Homem 03: Tem professor que incentiva e tem professor que sufoca. Tem o que está ali incentivando e aquele que fala: Alá, o Enem tá chegando, o Enem tá chegando, tem que fazer. Outros que falam, eu vou te ajudar.

Mulher 01: Acho que falta mais isso aqui, mais professores pra ajudar.

A metade não fez o ENEM e justificou falta de preparo para fazer a prova ou não saber que curso fazer. Trata-se de uma clara demonstração de desigualdade social, pois, muito provavelmente tal situação não ocorreu com estudantes do ensino privado do município. Pelo relatado, a escola não se organiza coletivamente para que todos façam o Enem, bem como não possui estrutura para ajudar os estudantes a pensarem em qual curso de graduação se inserir.

No contexto escolar jovem e aluno costumam ter fronteiras bem definidas. Os jovens pouco expressam seus sonhos, desejos e perspectivas de vida.

$\mathrm{Na}$ frequência cotidiana à escola, o jovem leva consigo o conjunto de experiências sociais vivenciadas nos mais diferentes tempos e espaços que, como vimos, constituem uma determinada condição juvenil que vai influenciar, e muito, a sua experiência escolar e os sentidos atribuídos a ela. Por outro lado, a escola que ele frequenta apresenta especificidades próprias, não sendo uma realidade monolítica, homogênea. Podemos afirmar que a unidade escolar apresenta-se como um espaço peculiar que articula diferentes dimensões. Institucionalmente, é ordenada por um conjunto de normas e regras que buscam unificar e delimitar a ação dos seus sujeitos (DAYRELL,2007, p. 1128).

Em geral, as experiências dos jovens a que se refere Dayrell (2007) são pouco aproveitadas nas escolas que tendem a ministrar conjuntos de conteúdos e ritmos alheios à vivência juvenil. Dubet (1994) através do conceito de experiência social destaca a importância processo de negociação entre jovens e o complexo escolar no processo de socialização. Segundo o autor, na contemporaneidade, as instituições sociais (aqui representada pela escola), não realizam mais o processo de socialização através de valores e princípios que a instituição escolar internaliza em seus alunos. O processo de socialização 


\section{RevistAleph}

é mediado pela própria experiência do aluno e por isso, a importância de valorizar suas vivências.

Atualmente os estudantes mais se configuram como outsiders de sua própria instituição escolar. Neste sentido, Becker (2008) considera que todos os grupos sociais criam e impõem regras sociais a fim de definir situações e tipos de comportamentos socialmente apropriados. Quando alguém age na contramão destas regras, infringindo as formas de conduta estabelecidas pelo grupo, o indivíduo acaba rotulado como um outsider, um desviante.

Consoante com apontamentos feitos pelo autor, existe grande número de regras na sociedade. Tais regras podem ser formalmente promulgadas por meio de leis e cujo poder de polícia do Estado será utilizado para impô-las. Em outros casos, acordos informais são estabelecidos e sanções também informais podem ser aplicadas no caso de seu descumprimento, como acontece na escola com os alunos que chegam atrasados ou não estão vestidos com o uniforme, cuja punição varia desde uma advertência verbal até a suspensão de frequentar as aulas por determinado número de dias, ou ainda quando o "tio" ameaça confiscar o baralho caso não se interrompa a partida de truco no desenrolar do intervalo.

Becker (2008) esclarece que os indivíduos podem ter opiniões diferentes acerca dos desvios. Alguns podem concordar ou discordar de seus julgadores, neste último caso naturalizando sua conduta e estranhando o juízo de valor emitido pelo julgador.

Mas a pessoa assim rotulada pode ter uma opinião diferente sobre a questão. Pode não aceitar a regra pela qual está sendo julgada e pode não encarar aqueles que julgam competentes ou legitimamente autorizados a fazê-lo. Por conseguinte, emerge um segundo significado do termo: aquele que infringe a regra pode pensar que seus juízes são outsiders (BECKER, 2008, p. 15).

Calha ressaltar que o tratamento aos desviantes, muitas vezes, estão condicionados, também, às relações de poder. Assim, na escola essa relação fica explícita porque professores não ficam sujeitos a regras de horários, uniformes, filas e outros e nem os gestores da escola explicam ou justificam a existências das regras, restando ao estudante jovem o papel de cumpri-las. Bourdieu (2003) se mostrava atento à produção de normas pelos adultos, o que redundava na desigualdade do poder de decisão nestes dois grupos etários. 


\section{RevistAleph}

Os jovens não se viam em condições de mudar as regras da escola e o preparo para a vida social estava pouco atento às práticas de participação cívica e dialógica entre sujeitos e instituições. Importante destacar que as responsabilidades não passam apenas pela escola e professores, "ela precisa estar presente no desenho das políticas públicas em educação, o que, de certa forma, vem ocorrendo de forma tímida" (GIL E SEFFNER, 2016, p. 180). Assim, os diálogos das comunidades escolares e possibilidades de interação mútua na gestão das escolas são, ainda, muito incipientes.

\section{Considerações Finais}

Este artigo é fruto de atividades reflexivas desenvolvidas no PIBID, o que demonstra o quão importante é a presença de bolsistas na escola, levando questionamentos de estudantes do ensino médio para reflexão na Universidade.

Esta experiência de pesquisa tem se mostrado importante ao destacar que as licenciaturas têm um papel reflexivo a cumprir, contribuindo para a formação de professores e debates nas comunidades escolares. Este trabalho estimulou a prática da pesquisa e reflexão sobre o ensino e trata de uma das formas de se ter futuros docentes mais conscientes dos ambientes escolares em que trabalharão.

Durante a realização do grupo focal identificamos o alto grau de maturidade dos participantes, bem como a satisfação dos mesmos em serem ouvidos. Há uma demanda de diálogo e de uma compreensão de que a educação precisa ser mais dialógica e com papéis menos pré-definidos, principalmente aqueles que nos remetem ao respeito às normas.

Vimos estudantes terminando o ensino médio muito críticos do ambiente escolar, embora gostem de estar ali pela sociabilidade que proporciona. Trata-se de jovens com vidas difíceis e que mesmo com políticas de democratização de acesso ao ensino superior terão muita dificuldade de ingressar em uma universidade, caso retrocedamos com políticas públicas mais elitistas tudo se torna ainda mais difícil. No ano de 2019 , metade não fez Enem e mesmo os que fizeram não se sentem preparados. Também não se sentiam à vontade na escola que contradizia suas culturas juvenis.

Nosso trabalho evidencia a urgência de práticas mais dialógicas na escola e demais projetos comuns que promovam cooperação entre adultos e jovens, conforme pudemos perceber na intervenção no banheiro da escola. Há muita margem para que ações como 


\section{RevistAleph}

aquela possam se proliferar pela escola. Projetos de cooperação apresentam enormes potencialidades. Neste sentido, os resultados desta pesquisa foram apresentados e debatidos com gestores da escola que prometeram repensar algumas normativas e conversar com os estudantes no início do ano letivo seguinte, o que pode gerar um ciclo virtuoso de colaboração e transformação.

As delimitações unilaterais do que pode e do que não pode acabar por não contribuindo para a construção da legitimidade junto aos estudantes e contribui para que não as cumpram e não se sintam corresponsáveis pela escola. Assim, há dificuldade de pensar como se sentiriam responsáveis pelo bairro, cidade e país em que vivem. A falta de participação na escola pode induzir processos de não participação na vida sócio-política.

\section{Referências}

ARIÈS, Philippe. As Idades da Vida. In: História social da criança e da família. Rio de Janeiro: Zahar, 2008.

BECKER, Howard. Outsiders. In: Outsiders: estudos de sociologia do desvio. Rio de Janeiro: Jorge Zahar, 2008.

BRASIL. PALÁCIO DO PLANALTO. Constituição da República Federativa do Brasil de 1988.

Disponível em: http://www.planalto.gov.br/ccivil_03/Constituicao/Constituicao.html. Acesso em: $21 / 05 / 2020$.

BOURDIEU, Pierre. Questões de Sociologia. Lisboa: Editora Fim de Século, 2003.

CHERVEL, André. História das disciplinas escolares: reflexões sobre um campo de pesquisa. Teoria \& Educação, Porto Alegre, v. 2, p. 177-229, 1990. Disponível em:

https://moodle.fct.unl.pt/pluginfile.php/122510/mod_resource/content/0/Leituras/Chervel01.pdf . Acesso em 21/05/2020.

DAYRELL, Juarez. A escola faz as Juventudes? Reflexões em torno da Socialização Juvenil. Educ. Soc., Campinas, vol. 28, n. 100 - Especial, p. 1105-1128, out. 2007. Disponível em https://www.scielo.br/pdf/es/v28n100/a2228100. Acesso em: 21/05/2020.

DUBET, François. Sociologie de l'experience. Paris: Seuil, 1994.

DURKHEIM, Émile. Educação e Sociologia. São Paulo: Editora Melhoramentos, 1965.

GIL, Carmem Zely Vargas, SEFFNER, Fernando. Dois monólogos não fazem um diálogo: jovens e Ensino Médio. Educação \& Realidade, Porto Alegre, v. 41, n. 1, 176 p. 175-192, jan./mar. 2016. Disponível em: https://www.scielo.br/scielo.php?script=sci_arttext\&pid=S2175-

62362016000100175 . Acesso em: 21/05/2020.

NÓVOA, António (2019). Os professores e a sua formação num tempo de metamorfose da escola. Educação \& Realidade, Porto Alegre, v. 44, n. 3, 2019. Disponível em: https://seer.ufrgs.br/educacaoerealidade/article/view/84910. Acesso em: 21/05/2020. 


\section{RevistAleph}

STECANELA, Nilda (2018). A coisificação da relação pedagógica no cotidiano escolar. Educ. Real, vol.43, n.3, p.929-946, 2018. Disponível em http://dx.doi.org/10.1590/2175-623678810. Acesso em: $21 / 05 / 2020$.

YIN, Robert K. O que é pesquisa qualitativa: e por que você cogitaria fazer este tipo de pesquisa. In: Pesquisa Qualitativa do início ao fim. Porto Alegre: Penso, 2016.

Data do envio: 10/04/2020 Data do aceite: 04/06/2020. 